YAK 347.4

DOI https://doi.org/10.32837/chc.v0i37.342

Гуйван Петро Амитрович,

кандидат юридичних наук, заслужений юрист України, професор Полтавського інституту бізнесу

ORCID https://orcid.org/0000-0003-3058-4767

\title{
ТЕОРЕТИЧНІ ПИТАННЯ БЕЗТИТУЛЬНОГО ВОЛОДІННЯ УПРОДОВЖ ПЕРЕБІГУ НАБУВАЛЬНОЇ ДАВНОСТІ
}

Постановка проблеми. Відновлення механізму застосування набувальної Аавності у вітчизняному законодавстві було викликане потребами удосконалення правового регулювання реально існуючих матеріальних взаємоАій у майновому обороті, тому воно позитивно оцінюється більшістю АосліАників. В нині Аіючій редакції українського цивільного права цей інститут дещо віАрізняється за змістом віА юриАичних конструкцій, що забезпечували Аосягнення такого ж результату в минулих кодифікаціях.

Неважко помітити, що правова структура коментованого правового механізму досить специфічна, особа може отримати право власності на чужу річ мише за наявності усіх чинників, які входять Ао його складу та мають юридичне значення. Як указано в статті 344 ЦКУ, право власності набуває особа, яка заволоділа майном у порядку, встановленому цією нормою, і продовжує надалі відкрито та безперервно володіти ним протягом визначених строків. Але головна увага законодавця і науковців приділяється тим правовим наслідкам, які наступають у разі закінчення набувального строку. 3 огляду на його досить протяжну тривалість актуальним $€$ питання про правовий статус окупанта упроАовж періоду, коли відбувається Аавнісне волоАіння чужою річчю.

Аналіз АосліАжень і публікацій. Наукова полеміка щодо того, є нетитульне володіння фактичним станом чи суб'єктивним правом, триває вже багато років. Ії̈ поява не пов'язана із запроваАженням Аавнісного набувного інституту, аАже такий характер утримання речі де-факто існував завжАи. Нині Аоводиться визнати, що в теорії цивільного права існують серйозні розбіжності та протиріччя щодо змісту тих матеріальних взаємодій, які характеризують безтитульне волоАіння майном.

У своїх роботах АосліАники надавали перевагу тій чи іншій концепції правової сутності незаконного володіння. Як результат було напрацьовано декілька теорій. Полярних позицій Аотримувалися Павел і Папініані у римському праві, Аернбург і ВіндшейА в німецькій цивілістиці, А.І. Мейер і Г.Ф.Шершеневич у російському науковому пошуку [1, с. 271]. Так, А.І. Мейєр стверджував, що Аавність не забезпечує жодного права, Аоки вона не призведе Ао права власності [2, с. 341].

Низка сучасних АосліАників також піАтримують цю тезу. Вони наголошують, що закон, кажучи про захист безтитульного володіння, якраз підкреслює відсутність такого права [3, с. 57-60, 154]. Аеякі АосліАники вважають юридичне володіння правом [1, с. 271]. Зокрема, С.Б. Гомолицький стверАжував, що володілець речі не може бути позбавленим позову Аля захисту свого права віА порушення його власником, байдуже попереднім чи новим: це випливає з поняття про загальні засаАи позову Аля будьякого права.

Відомий цивіліст початку XX століття В.М. Хвостов вказував на наявність у волоАільця правового статусу, який має урізаний зміст [4, с. 273]. 3 цією позицією погоджується i К.І. Скловський, аналізуючи вже сучасне російське цивільне законодавство. Він зазначає, що, хоча незаконне володіння і має ознаки певного права, воно все ж не є абсолютним, оскільки не включає в себе можливість протиставлення 
іншим правам (зокрема, праву власника чи титульного володільця, віА яких воно не захища$\epsilon_{\text {сьс }}{ }^{1}$ ). Тому це урізане право співвіАноситься 3 іншими речовими абсолютними правами як факт [5, с. 290-292].

Як бачимо, це питання має Аосить полемічний характер. Тому з'ясуванню головних аспектів стосовно наявності в окупанта права володіти чужим майном і захищати його, в тому числі віА посягань власника, упродовж перебігу Аавнісного набувного строку, є метою статті.

ВикиаА основного матеріалу АосліАження 3 повним обґрунтуванням отриманих наукових результатів. Зі встановленням інституту набувальної Аавності питання отримало ще більшої актуальності та гостроти. Причому наукові піАходи зАебільшого ґрунтувалися на правовій регламентації описуваного явища в нормах чинного законодавства. Тож нині низка вчених впевнено ведуть мову про те, що нетитульний володілець має конкретне суб'єктивне майнове право, яке випливає із приписів цивільного законодавства. Прихильники цієї концепції також визначають і сутність подібного повноваження Аобросовісного набувача. Зокрема, стверджується, що останній разом із майном отримав і право на тривале Аавнісне волоАіння ним.

На Аумку В. Слищенкова, зміст такого повноваження полягає у праві на отримання власності [6, с. 2]. СліА зазначити, що цей піАхіА російських науковців насампереА зумовлений відомою позицією Конституційного Суду Російської Федерації, викладеною у резолютивній частині постанови віА 21 квітня 2003 року № 6-П. в ній, зокрема, стверАжується, що нетитульний володілець має суб'єктивне право, щоправда воно Аосить абстрактно зветься просто майновим правом без розкриття його змісту.

Подібні Аискусії знайшли відображення у суперечливості нормативних актів, що становить серйозні проблеми Аля практики. Очікувалося, що віАновлення Аієвого юридичного інструментарію щодо набуття права власності на чуже майно за Аавністю володіння вирішить проблему із статусом нетитульного набувача. Але насправді так не сталося. Мушу зауважити маконічність законодавства у цьому питанні: всім аспектам щодо підставності та порядку застосування Аавнісного

\footnotetext{
${ }^{1}$ СліА зазначити, що віАповіАно Ао п. 2 ст. 234 ЦК РФ, на віАміну віА аналогічного правила в українському ЦК, особа, яка володіє майном як своїм власним протягом набувальної давності має право на захист свого володіння мише проти третіх осіб. Це право не поширюється на правовий захист проти порушень з боку власника майна чи іншого титульного утримувача.
}

набувального механізму присвячена мише одна стаття в українському Цивільному кодексі.

Попри прогресивність його запровадження зміст нормативного правила поки що не може визнаватися адекватним реальним суспільним взаєминам. ААже після принципового рішення про віАновлення правової можливості набуття власності на чуже майно за Аавністю володіння всі чекали, що далі відбудеться детальне розкриття змісту віАповіАного правила. Тим самим відбулося б виявлення специфічних рис, закладених у ньому. Та в ст. 344 ЦКУ практично нічого не йдеться про особливості реалізації повноважень нетитульного володільця протягом набувальної Аавності.

Навіть поверховий аналіз коментованої статті Аозволяє зробити висновок, що описане в ній тривале незаконне володіння аж ніяк не можна кваліфікувати як констатацію фактичного майнового стану речі. Таке володіння є нічим іншим як реалізацією певного повноваження. Ось тут і виникає найбільша проблема: на що ж спирається правоволодіння такої особи протягом набувального строку? На жаль, закон з цього приводу мовчить. Разом із тим є всі підстави вважати, що залишення цього питання без задовільного тлумачення чи коригування відповіАних правових норм означає ухилення віА проблеми замість пошуку ефективного рішення.

Спробуймо більш Аетально розібратися із правовим статусом особи, яка без належної піАстави володіє чужим майном Аля давності. Аналіз як самої сутності такого утримання майна, так і чинного законодавства в цій царині Аозво^яє Аійти висновку про правову природу вказаного віАношення. Межі зАійснення повноважень набувача встановлені нормативно: добросовісне отримання майна плюс відкритість і безперервність володіння протягом визначеного часу віА встановленого у законі терміну. І ^ише повною реалізацією (вичерпаністю) закладених у такому повноваженні можливостей вАасться пояснити набуття іншого матеріального права - власності.

Аналіз віАповіАних глав Цивільного кодексу України теж приводить АосліАників питання Ао висновку про наявність правової підстави Аля нетитульного володіння чужою річчю. Це і не Аивно. Законодавство України, як це випливає з його буквального тлумачення, регламентує таку можливість. Із положень глави 31 ЦКУ, в якій ілеться про регулювання нормативно-санкціонованого права володіння чужим майном, ніяк не описано ії застосування виключно до титульних 
володільців. Тож за великим рахунком нетитульне володіння чужою річчю може бути віАнесене Ао інших речових прав у контексті змісту ст. 395 ЦКУ. Відповідно Ао ст. 396 Цивільного кодексу вказані у попередній нормі суб'єкти мають право захистити свої права всіма законними способами, в тому числі і віА власника.

Правовий статус суб'єкта, який незаконно володіє чужою річчю, побічно піАтверджується і в результаті Аослідження сутності інших нормативних приписів. Скажімо право володіння за змістом ч. 2 ст. 399 ЦКУ припиняється в разі витребування майна власником. Подібне витребування у цивільному праві віАнесене Ао речових способів захисту права власності і має назву вінАикаційного Аомагання [7, с. 97]. За своїм визначенням віндикація $€$ вимогою про відібрання речі у нетитульного володільця (ч. 1 ст. 388 ЦКУ). Та, кажучи про припинення права шляхом відібрання майна у незаконного володільця, закон легітимізує матеріальне право, яке перебувало у володільця до відібрання речі.

I все ж лише згаАки про можливість існування суб'єктивного права володіння чужою річчю замало. Набагато важливішим чинником Аля його реального зАійснення є встановлення практичної можливості реалізації захисного повноваження, описаного у ст. 396 ЦКУ, в разі порушення такого права. Питання, з цим пов'язані, зАебільшого перебувають в морально-етичній площині: чи є суспільно прийнятним захист незаконного володільця проти, наприклаА, власника майна? А наАто тоді, коли окупант $€$ не тільки нетитульним, а й недобросовісним? Сумніви ці небезпідставні.

Маємо погодитися, що навряА чи Аоцільною вигляАає повна юрисАикційна піАтримка особи, яка позбулася майна, яке вона перед тим вкрала чи іншим способом недобросовісно набула ${ }^{2}$. Тож, якщо вже вести якусь мову про можливий позовний судовий захист незаконного володільця, тим більше віА власника, то це треба робити тільки щодо Аобросовісного набувача, тобто такого, який утримує річ протягом Аавнісного набувального строку. Проте й тут існують Аосить серйозні проблеми, пов'язані з неоднаковим сприйняттям громадської потреби та методології формування такої охоронно-правової ідеології.

${ }^{2}$ Хоча і в цьому випадку зайва категоричність $€$ невдалим раАником. ААже ми можемо впасти в іншу крайність. Позбавлення особи, яка придбала крадену річ, про що вона мала знати, всілякого правового захисту, може призвести до заохочення випадків самоуправства. I не тільки з боку власника, а й третіх осіб. Тим більше, що межа між добросовісним і неАобросовісним набуттям іноді є Аосить примарною, визначається мише в судовому порядку.
Різні концептуальні підходи перешкоджають напрацюванню єАиного механізму Аієвого захисту Аавнісного володіння. НаприклаА, існують певні віАмінності щодо визначення об'єкту, який захищається, у ст. 234 ЦК РФ і ст. 396 ЦК України. Український закон веде мову про захист права, тоді як російський - про захист фактичного володіння. Остання Аефініція дає ще одну можливість окремим АосліАникам вести мову про віАсутність правових засаА Аля безтитульного волоАіння [8, с. 487].

Більш глибоке вивчення питання фактично призводить Ао заперечення самому собі: захист Аавнісного володільця переАбачає виявлення прав на майно (суд мусить вияснити, якими правами наділені сторони, інакше норма не може бути застосована: на практиці це завжАи має місце і становить основний зміст спору). Та чи взагалі може захищатися неправомірне Аіяння всупереч праву? Питання майже риторичне. У ст. 15 ЦКУ зазначено, що об'єктом захисту є цивільні права та інтереси.

Може, нетитульне володіння охоплюється поняттям інтересу? Ні. В науці загальноприйнятною є Аумка про взаємопов'язаність суб'єктивного права та інтересу. Він виявляється в тому, що інтерес $є$ передумовою виникнення суб'єктивних цивільних прав, а останні є правовим засобом заловолення інтересу, оскільки саме через право інтерес реалізується [9, с. 98]. Тож інтерес завжди має правовий характер, а за відсутності суб'єктивного права чи інтересу немає і об'єкта волоАіАьницького захисту.

Тому ЄАино проАуктивним вигляАає цивілістичний посил, згіАно з яким чинні правові акти покликані регулювати не якесь абстрактно існуюче, випадкове явище, об'єктивний стан матерії, а конкретний соціально Аопустимий рівень взаємодій, які хоча і виникли всупереч праву, але з огляду на їхню специфіку заслуговують на нормативну забезпеченість та охорону. При цьому відповіАні положення законодавства, в тому числі щодо активного власницького захисту, мають не Аекларативний, а цілком прагматичний зміст, який мише потребує деякої конкретизації.

Подібна точка зору спостерігається у працях низки сучасних цивілістів, які погоджуються з тезою, що Аавнісне володіння спирається на певне встановлене законодавством суб'єктивне право його носія. I саме із безспірності цього права витікає юридична можливість і необхіАність юрисдикційного захисту володіння, яке не забезпечене правовим титулом. 
Г.А. ГаАжиєв, розглядаючи прописане в ч. 2 ст. 234 ЦК РФ положення про право на захист свого володіння у системному взаємозв'язку зі ст. 11 ЦК РФ про судовий захист порушених цивільних прав, розцінює їх як визнання конкретного правового титулу володільця. Він цілком справеАливо виходить із того, що позовне Аомагання може виникати мише при порушенні певного суб'єктивного права, у цьому випадку речового [1, с. 272-273].

Часто сереА зумовлених правовим регулюванням матеріальних відносин можна зустріти належні особі суб'єктивні права, не забезпечені можливістю юриличного захисту в разіпорушення. Аекларативний характер окремих повноважень вже Аавно зафіксований у нашій цивілістиці [10, с. 96-97]. Такого вигляду набуває, наприклаА, охоронне право кредитора після спливу позовної Аавності: в силу припису ч. 1 ст. 267 ЦКУ вимога продовжує існувати, але вона втратила позовну властивість. Тож існування правових ситуацій, коли порушене право не може бути захищене в судовому порядку, є цілком припустимим. Але взаємовіАношення зворотного змісту уявити собі не можна. Якщо вже існує встановлене законом позовне Аомагання, то обов'язково мусить існувати і суб'єктивне право, порушення якого привоАить право на позов у дію.

Отже, отримавши нове речове право, володімець набуває не тільки можливість безпосереАнього фізичного тримання речі, а й певну міру майнової влади. Він має право впливати на майно та віАбивати зазіхання на своє володіння з боку третіх осіб. Вказані повноваження не сліА обмежувати тільки пасивним захистом свого володіння. Власне кажучи, український закон також вказує на можливість судової реалізації вимог незаконного володільця до інших осіб.

Той факт, що така особа має як суб'єктивне право на утримання речі, так і можливість його захисту, піАтверАжується не тільки загальним правилом ст. 396 ЦКУ, а й положенням ч. 2 п. 3 ст. 344 ЦК України. В ній передбачається преА'явлення позову Аавнісним володільцем про витребування майна в разі його втрати останнім не зі своєї волі. Фактично вказані нормативні правила Аозволяють вести мову про надання такому суб'єктові притаманних власнику повноважень щоАо, наприклаА, преА'явлення позову про витребування майна. При цьому судовий захист такого володіння не обмежується вимогами Ао третіх осіб. Тому у цивілістичній літературі прийнято вважати, що Аомагання про витребу- вання майна в разі втрати його володільцем не зі своєї волі можуть спрямовуватися і на алресу власника або іншого титульного волоАільця. Принаймні саме таким чином зазвичай тлумачиться це правило на теоретичному рівні.

Чи так це насправаі? Аозволю собі поставити піА сумнів практичну Аієвість згаданого механізму. Передбачений у ч. 2 п. 3 ст. 344 ЦКУ позовний захист ніяк не може ототожнюватися із римським praescriptio longi temporis, яке як Аавнісне володіння було одночасно і обґрунтуванням заперечень проти вимог неАбайливого власника, і спеціальною піАставою Аля позовного Аомагання володільця, який міг витребувати річ (навіть якщо вона потрапляла Ао власника) [11, с. 231], зокрема, в силу більш вузької сфери застосування.

Крім того, залишається спірним питання про практичну можливість аргументованого обґрунтування володільцем свого матеріального права на утримання майна при преА'явленні такого позову. Уявімо собі ситуацію, коли власник, що втратив можливість судового витребування або третя особа силоміць чи іншим шляхом поза волею давнісного володільця віАбере у нього річ. Володілець преА'явив позов про витребування цієї речі. Але яке повноваження він протиставить праву власності чи титульного володіння? Навіть коли вважати нетитульне володіння таким, що забезпечене правом, його протиставлення власності не вигляаає перспективним.

На жаль, практика захисту володіння нині не напрацьована, а українські суди переконані, що такий захист можливий мише через процедуру визнання права власності, тому він завжди буде спрямований на користь власника, навіть коли той самовільно вияучив майно у Аобросовісного володільця. Певною мірою такий піАхіА пояснюється існуючим станом товарно-матеріальних віАносин, коли відверта підтримка незаконного набувача навряд чи отримає суспільне схвалення.

Як же забезпечити ефективність задекларованого нормативно-правового інструментарію? Коли закон прямо веде мову про можливість позовного захисту Аавнісного волоАіння, він також мусить визначити конкретні способи його реалізації. При цьому неріАко нові піАхоАи виявмяються у призабутих старих.

Як вже згадувалося, у цивільному праві, починаючи 3 римських часів, існував юридичний механізм посесорного захисту, який застосовувався незалежно віА наявності титулу у позивача (possessorium) і був покликаний запобігти 
самоуправству [12, с. 87-88]. у такому процесі немає потреби не тільки доводити, а й навіть посилатися на право, Аосить мише Аовести факт свого володіння [13, с. 201]. Зміст такого захисту полягає у тому, що володілець протистоїть будь-якому загарбнику, незалежно віА наявності в останнього титулу. Тому самоуправство навіть власника повинне вважатися Аією поза межами права, віА якого є захист. I саме у такому піАході, коли йдеться не про право взагалі, а про речі набагато вищі та ілеальні, затвердження поваги Ао ^юАської особистості, яка зростає у своїй самосвідомості, вбачалося значенням активного захисту володіння [14, с. 229].
Висновки 3 Аослідження та перспективи подальших розвіАок у цьому напрямі. Популярна в мітературі ідея запровадження посесорного захисту поки що не знайшла реального втілення. Протистояння ідеальної теорії та приземленої практики продовжується на рівні коректної полеміки. У результаті такого перманентного стану казуальні питання відАані на відкуп правозастосовному органу. Як завжАи, коли “буксує" нормотворча Аумка. Це питання потребує подальшого Аетального вивчення науковцями та законодавцем, нормативного відображення, але воно не є предметом глибокого досліАження в цій праці.

\section{МITEPATУPA:}

1. Гаджиев Г.А. О субъективном имущественном праве добросовестного владельца. Актуальные проблемы науки и практики коммерческого права. Сборник научных статей. М. : Волтерс Клувер, 2005, Вып. 5. С. 269-278.

2. Мейер Д.И. Русское гражданское право. Ч. 2 (по изданию 1902 г.). М. : Статут, 1999. 455 с.

3. Лапина В.В. Институт приобретательной давности и способы защиты давностного владения в гражданском праве России / Автореф. дисс. канд. юрид. наук: 121.00.03. М., 2006. 186 с.

4. Хвостов В.М. Система римского права. Учебник. М. : Спарк, 1996. 310 с.

5. Скловский К.И. Собственность в гражданском праве. Учебно-практическое пособие, 2-е изд. М. : Дело, 2000.512 с.

6. Слыщенков В. Утерянный институт права. ЭЖ-Юрист. 2003. № 6. С. 2-3.

7. Igering. Entwickelungsgeschichte des rom. Rechrs. Leipzig : Breitforf \& Bartel und Dunder \& Bumblot, 1894. 124 S.

8. Скловский К.И. Собственность в гражданском праве. 5-е издание перераб. М. : Статут, 2010. 893 с.

9. Тархов В.А. Гражданское право. Общая часть. Курс лекций. Чебоксары : Чув. кн. из-во, 1997. 331 с.

10. Грибанов В.П Пределы осуществления и защиты гражданских прав : монография. М. : Издательство Московского университета, 1972. $284 \mathrm{c.}$

11. Римское частное право. Учебник для бакалавров. / Под ред. И.Б. Новицкого, И.С. Перетерского / М. : Юрайт, 2013.607 с.

12. Покровский И.А. История Римского права. Издание 3-е, исправленное и дополненное. 1917. Ст.-Пб., Allpravo. Ru. 2004. $138 \mathrm{c}$.

13. Римское частное право : Учебник / Под ред. И.Б. Новицкого и И.С. Перетерского. М., 1996. 544 с.

14. Покровский И.А. Основные проблемы гражданского права. М. : Статут, 1988. 353 с.

\section{Гуйван Петро Амитрович}

\section{ТЕОРЕТИЧНІ ПИТАННЯ БЕЗТИТУАЬНОГО ВОЛОАІННЯ УПРОАОВЖ ПЕРЕБІГУ НАБУВААЬНОЇ ААВНОСТІ}

Робота присвячена науковому досліАженню актуального питання правового статусу Аобросовісного набувача чужої речі в періоА, Аоки він здійснює давнісне володіння в межах набувального строку. Автор детально аналізує наукову полеміку щодо того, $є$ нетитульне володіння фактичним станом чи суб'єктивним правом. На користь кожного з цих підходів у літературі висловлені думки поважних вчених.

Зазначається, що питання отримало ще більшої актуальності та гостроти, враховуючи відновлення цивільного інституту набувальної давності. Натепер наукові концепції почали ґрунтувалися на правовій регламентації описуваного явища в нормах чинного законодавства. 3 огляду на це все більш очевидним стає факт, що зАійснювати володіння не титульний набувач може лише в межах свого суб'єктивного права навіть попри бажання та волю власника майна. Це підтверджується запровадженням (на жаль, поки що декларативним) і правової можливості захисту такого права у випадку вимушеної втрати володіння. Автор статті також дотримується цієї юридичної позиції.

У статті вказано на непослідовність і кволість законодавця, який не надає задекларованому ним праву реального практичного механізму втілення. В той же час реальні правовідносини за наявності протилежних інтересів неволодіючого власника і володіючого Аобросовісного окупанта часто опиняються в тупиковій ситуації.

За таких обставин єАино продуктивним є цивілістичний посил, згіАно з яким чинні правові акти покликані регулювати не якесь абстрактно існуюче, випадкове явище, об'єктивний стан матерії, а конкретний соціально Аопустимий рівень взаємодій, які хоча і виникли всупереч праву, але з огляду на їхню специфіку заслуговують на нормативну забезпеченість та охорону. Тобто, має бути забезпечений Аієвий інструментарій зАійснення та захисту суб'єктивного права на Аавнісне володіння чужим майном.

Автор вбачає вирішення цього питання у площині запровадження конкретного механізму посесорного захисту такого володіння. При цьому має враховуватися, що позовне Аомагання може виникати лише при порушенні певного суб'єктивного права, у цьому випадку - речового. Отримавши нове речове право, володілець набуває не тільки можливість безпосереднього фізичного тримання речі, а й певну міру майнової влади, він має право відбивати зазіхання на своє володіння третіх осіб і навіть власника.

Киючові слова: захист володільця, посесорний позов, давнісне володіння. 


\section{Guyvan Petro}

THEORETICAL ISSUES OF TITLELESS POSSESSION DURING THE ACQUISITION PERIOD

The work is devoted to the scientific research of the actual question of the legal status of a bona fide acquirer of another's thing during the period when he exercises the ancient possession within the period of acquisition. The author thoroughly analyzes the scientific controversy of the controversy as to whether he has a non-titular possession of fact or subjective law.

For the benefit of each of these approaches, the opinions of distinguished scientists have been expressed in the literature. It is noted that the issue has become even more urgent and acute, given the restoration of the civilian institution of limitation. At present, scientific concepts have begun to be based on the legal regulation of the phenomenon described in the rules of current law. In view of this, it is becoming increasingly apparent that a non-title acquirer can only exercise possession within the limits of his subjective right, even with the wishes and will of the property owner.

This is confirmed by the introduction (unfortunately, as yet declarative) and the legal possibility of protecting such a right in case of forced loss of ownership. The author of this work is also in this legal position. Meanwhile, the article notes the inconsistency and weakness of the legislator, which does not give him the right to a real practical mechanism of implementation.

At the same time, real legal relationships in the presence of opposing interests of the non-possessing owner and possessing a bona fide occupier often find themselves in a deadlock. In such circumstances, the only civilian message seems to be productive, according to which valid legal acts are intended to regulate not some abstractly existing, accidental phenomenon, objective state of matter, but a specific socially acceptable level of interactions, which, although arising out of law, in view of their specificity deserve regulatory support and protection.

That is, an effective toolkit should be provided for the exercise and protection of the subjective right to antiquity of another's property. The author sees the solution of this issue in the field of introduction of a specific mechanism of seizure protection of such possession. It should be borne in mind that a claim can only arise in violation of a certain subjective right, in this case - a real one. Having obtained a new real right, the owner acquires not only the possibility of direct physical possession of the thing, but also a certain measure of property power, he has the right to repel the encroachment on his possession of third parties and even the owner.

Key words: protection of the owner, possessory claim, antiquity. 